\title{
The impact of the E75 railway line's modernization on the development of the Warsaw Metropolitan Area
}

\section{Bartłomiej Drąg, Dariusz Piwowarczyk}

\begin{abstract}
The aim of the paper is to present the most important results of the research carried out for the case study on the effects of Rail Baltica investments in the Warsaw Metropolitan Area (WMA) urban node. The research was carried out as part of the EU project NSB CoRe (North Sea Baltic Connector of Regions). In the article the main conclusions from the study are presented, describing changes that have supervened in the analyzed area (communes within the boundaries of the WMA, at a distance of up to $3 \mathrm{~km}$ from the E75 railway line and ones crossed by national road 8/S8) in the period of the E75 line's modernization. The analysis focuses on changes in settlement structure as well as the functioning of railway transport, with an assessment of the improvements by its users. Conclusions from the analysis of changes in the spatio-functional and socio-economical dimensions are described and concern the number of building licenses granted, changes in population size, changes in the number of registered natural person business entities, changes in the number of transactions on the real estate market. Moreover, in the area of transport, the paper presents an assessment of the quality of railway services on the E75 line through passengers' opinions and the integration of the Baltic railway with alternative transport modes.
\end{abstract}

Key words: Warsaw Metropolitan Area, E75 railway line, Baltic-North Sea transport corridor, Rail Baltica, NSB CoRe project

\section{Introduction}

The case study entitled The impact of the E75 railway line modernization on the development of the Warsaw Metropolitan Area (hereinafter referred to as the case study) was prepared by the Mazovian Office for Regional Planning in Warsaw in 2018 as part of the NSB CoRe (North Sea Baltic Connector of Regions) international project, funded by the Baltic Sea Region Interreg Programme. The article presents the most important results of the analyses carried out within the aforementioned case study. The project dealt with the North Sea - Baltic Sea Trans-European Transport Network (TEN-T) corridor. The key element of the corridor is Rail Baltica which links the Baltic countries with other EU countries. The outcome of the NSB CoRe project is to provide possible ways of increasing the availability of the eastern Baltic Sea region through developing solutions aimed at eliminating bottlenecks in border areas and synchronizing long-distance transport with local transport systems. Rail Baltica will enable fast transport of people and goods between metropolises and make it possible to connect freight and passenger transport with other elements of the European transport network. 
In Poland, Rail Baltica includes two international railway lines: the E20 (KunowicePoznań-Warsaw) and the E75 (Warsaw-Białystok-Ełk-Olecko-Suwałki-Trakiszki) which run through the Mazovia Region.

The case study involved an initial evaluation of the effects of the Rail Baltica undertaking on the Warsaw Metropolitan Area (hereinafter referred to as the WMA). The timeframe for the case study was the period during which the E75 railway line was being modernized, i.e. 2012-2016, starting from the signing of an agreement with the contractor of the modernization. The case study area was delimited within the WMA to include communes located within a $3 \mathrm{~km}$ radius of Rail Baltica as well as communes through which runs national road no. 8 (express road S8) (Fig. 1).

The case study was developed in three dimensions: spatio-functional, socio-economic and transport. The aim of this article is to focus on the analysis of selected processes: spatial (building licenses granted), socio-economic (demographic processes, natural person business entities, the real estate market) and changes in the field of transport (the quality of services provided by railway companies, passengers' opinions on railway transport operation and integrating Rail Baltica with alternative transport modes).

\section{Spatio-functional conditions of the case study area}

In the 16th century, road routes had an impact on shaping the arrangement of the settlement network in the case study area. ${ }^{1}$ The most important routes, including the Great Lithuanian Route - one of the main roads of the Kingdom of Poland - led to the Grand Duchy of Lithuania. Road routes were the basis for spatial development, as a result of which the first settlements in the case study area were established. For centuries, the development of settlements along road routes was associated with the function of roads, i.e. they were places of increased trade and social activities. Road routes stimulated the economic development of settlements, which entailed population growth and spatial changes. This model of settlement development survived until the second half of the 19th century, when the first railway lines started to be constructed. The opening of railway lines was an important factor that shifted the center of spatial development in the case study area. Trains became the dominant means of transport and replaced road transport, which was less effective, for almost 100 years. As an alternative to road routes, trains provided a fast and efficient way of transporting goods, raw materials and people. The construction of one of the main railway lines in the Kingdom of Poland in 1862, the Saint Petersburg - Warsaw Railway (which connected the administrative center of the Kingdom of Poland with the capital city of the Russian Empire at that time), led to an increase in the attractiveness of areas located along the railway line as a place to live and carry out investment projects near Warsaw. Consequently, the number of people living

\footnotetext{
${ }^{1}$ The oldest acquired data on the historical arrangement of settlement and road networks (before the railway line was opened) comes from a publication by the Institute of History of the Polish Academy of Sciences: Atlas historyczny Polski, Mazowsze w drugiej połowie XVI w.
} 
I. Analyses and Studies / Analizy i Studia

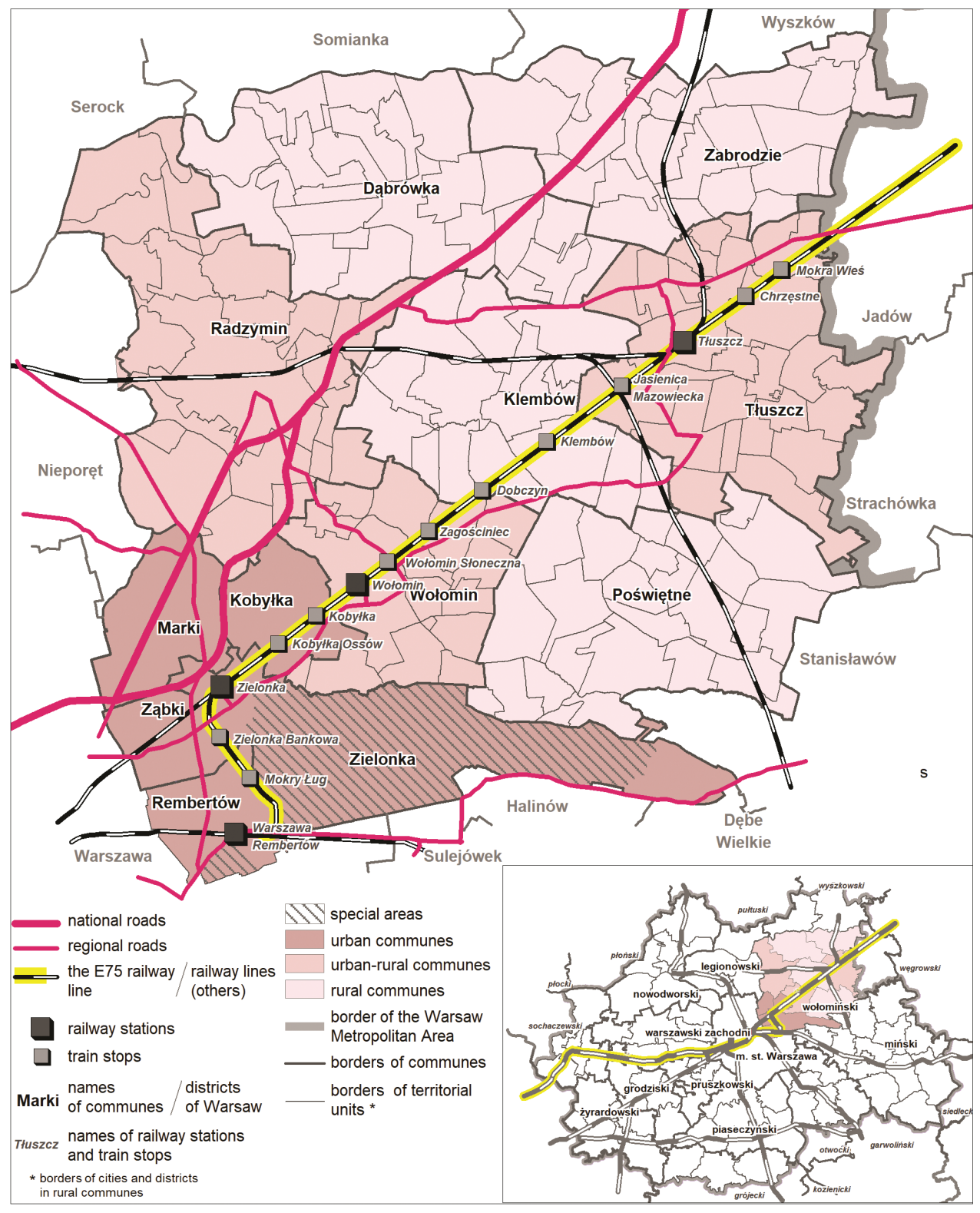

Fig. 1. Case study area set against the administrative division of the WMA (large map: communes and territorial units, small map: counties and communes) Source: study of the MBPR on the basis of BDL, PZPWM, www.mapa.plk-sa.pl 
in those areas increased rapidly. ${ }^{2}$ The population growth led to the granting of town charters to several settlements located along the railway line (currently the E75). To this day, these locations are towns and maintain their development potential.

Over the several decades during which railway transport was dominant, the core of the current settlement arrangement developed, while the growing importance of road transport since the 1950s has not had a dramatic impact on the center of this settlement arrangement. Shaped in the past centuries, the routes of major roads are similar to the current transport routes of regional and national significance. Together with railway lines, they constitute the main elements of the transport network in the case study area.

Buildings in the case study area are mainly located in strips along the main transport routes departing from Warsaw. Most of the built-up and urban areas (approx. 54\%) are concentrated in urban centers located next to the international transport corridor. Urban areas located next to the E75 railway line are characterized by a fairly densely built-up area due to existing spatial barriers within towns' boundaries - natural (forest complexes, river valleys) and artificial (the said railway line) ones. Invested areas are - to a lesser extent village buildings, located mainly along local roads. In addition, there are a lot of building enclaves, separated from the spatial layouts of villages, which are disharmonious elements of the agricultural production space. The E75 railway line clearly divides the case study area into two zones which differ in terms of the intensity of urbanization processes. Most of the invested areas are located to the north of the said railway line whereas the area situated to the south is developed in a more extensive way. The scale of development of settlement units varies due to the fact that national road no. 8 (S8) and the majority of transport routes of greater than local importance are located in the northern part. In the case of the north-western part, natural and recreational amenities related to the valley of the Bug river and Zegrze reservoir located nearby are additional factors determining the development of buildings.

Developed areas are dominated by residential areas with a predominance of single-family buildings and associated minor service facilities as well as, to a lesser extent, single-family homesteads and summer buildings (associated with the valley of the Bug river) in villages. Large complexes of multi-family buildings are located in Rembertów (an outer district of Warsaw) and in the suburbs of the capital city (Ząbki, Marki, Zielonka). In the central parts of urban areas (mostly formed along the main transport routes), there are densely built-up areas of service and residential buildings that create a mosaic of intertwining service complexes (public, religious and commercial services) and single-family and multi-family buildings (small housing estates). Large-scale service buildings (transport, logistic and commercial services) contribute to the creation of production, service and technical areas, mostly located in the suburbs of towns and villages with ranges of socio-economic activities. Special (military) areas are located in the southern part of the area (in the district of Rembertów and in the town of Zielonka) and they cover a total surface area of 6040.1 ha (7.2\% of the analyzed area). Due to their functions, they are closed areas.

\footnotetext{
${ }^{2}$ Wołomin - the most populated town in the case study area - had 91 inhabitants in 1823, while in 1919 (57 years after the railway line had been built) this number was approx. 13,000 according to an article in Rocznik Mazowiecki: Wołomin na tle innych nowych miast podstołecznych w latach 1896-1919.
} 
Spatio-functional links occurring between settlement centers are a consequence of increased suburbanization processes around Warsaw which is a catalyst for development that stimulates and transforms areas in its immediate surroundings. The settlement centers located near Warsaw (Rembertów district-Ząbki-Marki-Zielonka-Kobyłka-Wołomin) form an integrated spatio-functional zone. Moreover, the spatial layouts of villages, located in the neighborhood of Zielonka, Kobyłka, Wołomin, Tłuszcz and Radzymin are in some places connected with the adjacent urban area. In 2012-2016 there were slight changes in the use of land, which did not have a significant impact on the spatio-functional structure of the case study area. The share of built-up and urbanized land increased at the expense of agricultural and forest areas (in the analyzed period there was an increase of built-up land by $0.6 \mathrm{pp}$ ).

To determine the trends of changes in the settlement space of the case study area, the scale of urbanization processes during the implementation of the railway modernization project and during a longer period prior to the modernization was analyzed. In 2000-2016 there has been an intensive development of urban areas in the case study area (Fig. 2). Designation of building land was characterized by an individual approach to space (changes concerned individual plots rather than high-density investment complexes), often not corresponding to the spatial policy of a commune. This was possible due to liberal legislation in the field of spatial management. The result is that local governments have little control over the sustainable development of communes.

In the following parts of the article, the most important conclusions from the analysis (conducted for the case study) are presented. Moreover, an attempt was made to identify the impact of the modernization of the E75 railway line on spatial, socio-economic and transport processes taking place in the case study area.

\section{Spatial and socio-economic dimension Demographic processes}

The construction of the Saint Petersburg-Warsaw Railway (nowadays the WarsawBiałystok E75 railway line) in the second half of the 19th c. acted as a catalyst, accelerating settlement processes. The construction of the railway line caused more people to live nearby as well as spurred the development of many socio-economic functions along the railway as for 150 years the areas located in its vicinity became attractive places to live and carry out a great number of investments. Settlement processes intensified due to the fact that Warsaw was located nearby. This is confirmed by the fact that the most populated settlement units the majority of towns in the case study area - are located within a $25-\mathrm{km}$ radius of the capital city and along the railway line.

During the E75 railway line's modernization, the population in the case study area went up by 14,900 . However, this growth was uneven in the case study area: the highest population growth took place in the areas with the highest population density, the following communes near Warsaw: Radzymin, Ząbki, Marki, Kobyłka. The increase was related to suburbanization of the capital of Poland. Population decline was noticed in the eastern - least populated - part. 

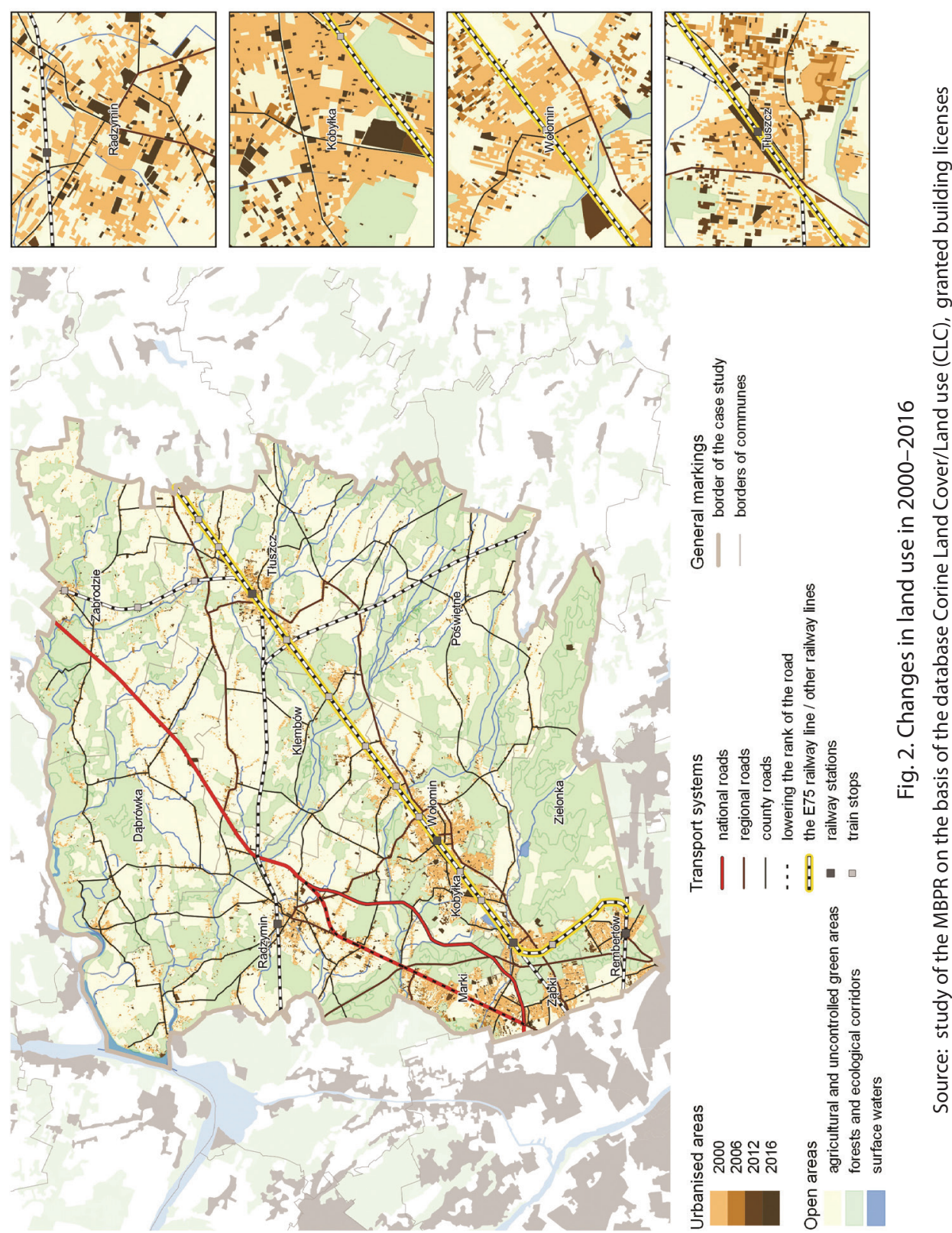
As a result, the demographic processes entailed considerable socio-economic differences in the case study area (Fig. 3B). The intensity of changes in the population increased along with the reduction of the distance from the railway line in question. Noticeable demographic changes also took place along national road no. 8, especially in the Radzymin commune, which results from the fact that suburbanization processes shifted from the communes near Warsaw (Ząbki, Marki, Zielonka, Kobyłka, Wołomin) to more attractive areas with higher greenfield reserves as well as from the growing impact of this road on the settlement processes in the case study area. An analysis of demographic changes prior to the the railway's modernization (2002-2006, 2007-2011) and during its implementation (2012-2016) showed no constant population growth. The highest population growth took place in 20072011, while there was a considerable decline in population growth in the area during the railway line modernization.

\section{Building licences granted}

Urbanization pressure during the E75 railway line modernization was analyzed in detail based on building licenses. In 2012-2016, 5,402 building licenses, 78\% of which were for new building investments, were granted in the case study area. They were mostly (approx. 90\%) residential building licenses. Over half (55\%) of the building licenses were granted in towns, the most in Marki (711) and Kobyłka (572), and in urban-rural communes: Radzymin and Wołomin (over 600). On the other hand, the smallest numbers of building licenses (below 150) were issued in rural communes: Zabrodzie and Poświętne which are located in the eastern part of the case study area.

The spatial distribution of building licenses issued demonstrated a considerable gap between the areas located north and south of the railway line. Little construction activity was registered in southern territorial units. The intensity of construction processes was more varied in the northern part. The development of construction investments in the case study area was primarily affected by the availability of the most important transport routes that make is possible to reach the capital city quickly. National road no. 8 is a rival route for the E75 railway line. Considerable construction activity was also noticed along the road. However, the scale of urbanization processes, especially along the section between Radzymin and the northern part of the case study area, was much smaller than in the areas closest to the E75 railway line. The most construction activity was generated by urban centers located mainly along the E75 railway line and in the areas in the vicinity of Warsaw. The spatial processes in the case study area were mostly associated with the suburbanization of Warsaw, the character of which is determined by the existing spatial barriers and local government policies. As the stimulus to development, Warsaw has a decisive impact on how urbanization processes take shape in the case study area. The share of building licenses issued in the suburbs of Warsaw in the total of of all building licenses granted in the case study area (63.5\%) serves as a confirmation (Fig. 3A). 
For most types of buildings there was no correlation between the number of building licenses granted and the distance from the E75 railway line. The only category in which such a correlation was visible were housing buildings. The share of building licenses granted for non-residential types of buildings did not increase along with the decrease in the distance from the railway line.

\section{Economic situation}

The number of national businesses entered into the National Official Business Register (REGON) is an important indicator of economic potential and the level of entrepreneurship. The analysis the level of entrepreneurship in the case study area in detail focused on natural person business entities (individual entities) registered in the Central Register and Information on Business (CEIDG) ${ }^{3}$ and classified under the 2007 Polish Classification of Business Activity (the PKD 2007).

In the years prior to the modernization of the E75 railway line and during the modernization, the intensity of changes in the number of registered business entities of natural persons was steadily on the rise. In 2016, 16,700 natural person business entities operated in the case study area, $80 \%$ of which were registered in or after 2000 . During the railway line modernization, the number of natural person business entities of went up by 6,900. The highest increase took place in the Wołomin and Ząbki communes (by 1,200 each) and in Marki (1,000). In addition, a high level of entrepreneurship was visible in Kobyłka Wołomin and the Rembertów district of the capital city of Warsaw (over 500 business entities). Apart from these towns, the areas that stood out in terms of the number of new companies (over 10) were territorial units situated east of Wołomin, along the E75 railway line and north of Marki, along national road no. 8 (S8), as well as near railway line no. 29. As the distance from the E75 railway line increased, the number of registered companies decreased sharply (Fig. 3C).

In 2012-2016, 2,100 trade and service companies were founded in the case study area, which amounted to $54 \%$ of all natural person business entities set up in that period. Companies focused on trade and services were predominant throughout the case study area. The highest share of this type of companies (over 70\%) was visible in Zielonka, Ząbki and the Rembertów district of the capital city of Warsaw. They were followed by companies operating in industry and construction $(1,300)$ and storage and transport (498). The distribution of companies in each group was similar, i.e. the highest number of companies were established in towns near Warsaw. What is more, a considerable number of such companies were established in the town of Tłuszcz and in rural areas (territorial units) situated along the E75 railway line and in several territorial units next to national road no. 8 (S8).

\footnotetext{
${ }^{3}$ These data do not refer to national businesses registered as commercial and private companies, foundations, and associations.
} 
I. Analyses and Studies / Analizy i Studia

A) Population changes

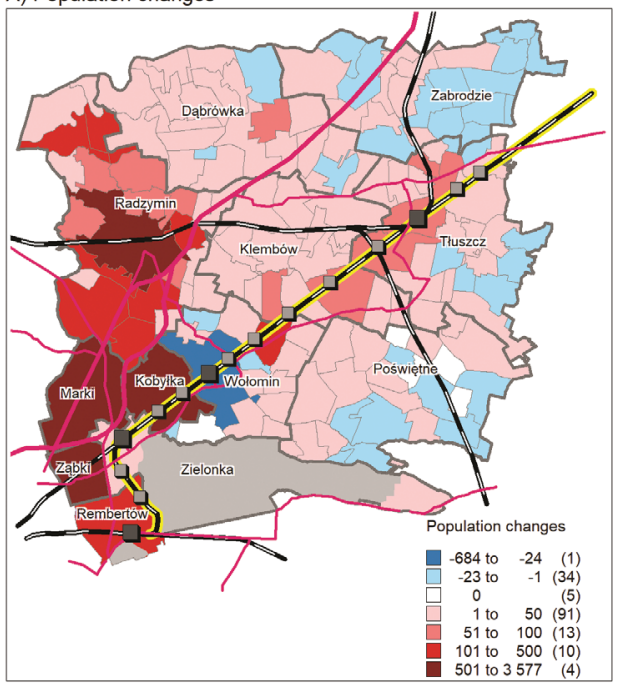

B) Number of building licenses granted in total

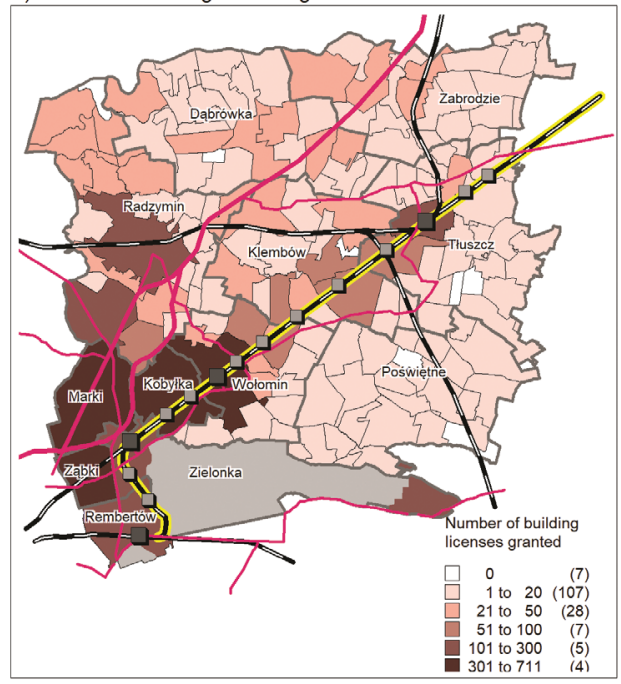

D) Number of transactions in total

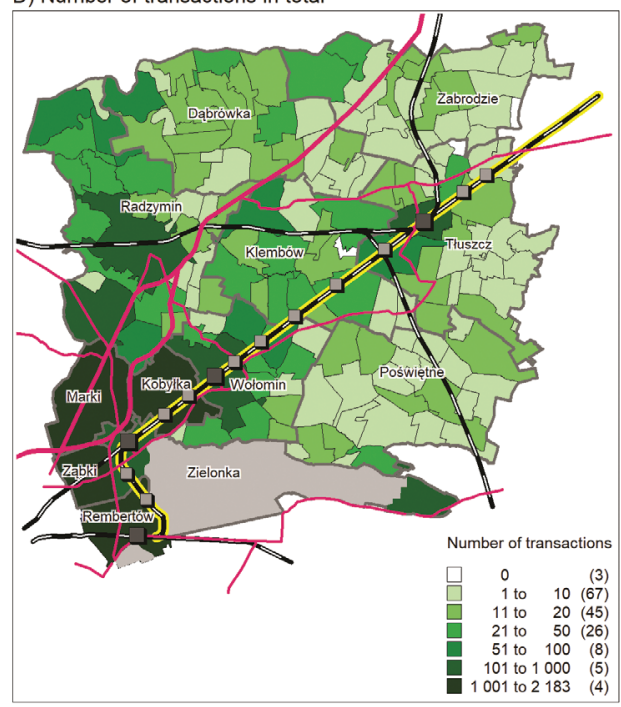

C) Number of registered business entities in total

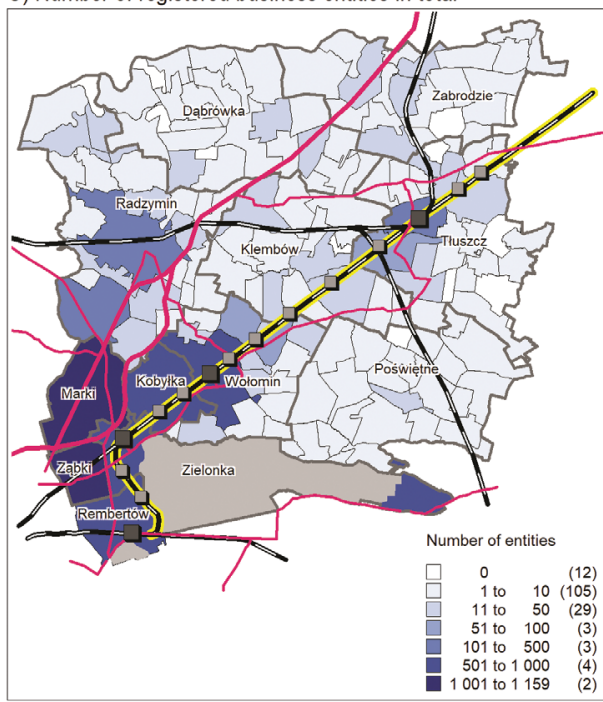

special areas

borders of communes

borders of territorial units

(borders of cities and districts in rural communes)

Fig. 3. Change of selected spatial and socio-economic indicators between 2012-2016

Source: study of the MBPR on the basis of data of county offices, commune offices,

Central Registration and Information on Business 
An analysis of the intensity of changes in the number of business entities of natural persons does not allow for a definite conclusion as to whether the increasing economic activity resulted from the E75 railway line's modernization, as it depends on a great number of factors. Transport accessibility and institutional facilities - including access to public services in urban centers ${ }^{4}$ - were among the main factors having an effect on the distribution of companies of natural persons, both during the railway project implementation and in the preceding years. The distance from large outlets and access to the labor force were also of particular importance; the highest number of companies was established in towns which have the highest population.

\section{Situation on the real estate market}

Changes in the real estate market during the analyzed period were the outcome of socio-economic processes, spatial phenomena shaped throughout history (location of the main urban centers along the E75 railway line), the legal situation in real estate trade, implementation of the national housing policy, credit terms of banks, activities of the Polish Financial Supervision Authority and many other, difficult to determine factors.

An analysis of selected economic indicators and the socio-economic tendencies in the case study area in 2004-2016 indicates improvements to the general economic situation of this area. This stable socio-economic situation is reflected in the growing number of real estate transactions and marginal fluctuations in real estate prices.

In 2012-2016, 10,700 transactions (2,100 per year on average) were made on the real estate market. The intensity of the processes occurring on the real estate market was greatly dependent on the location in relation to Warsaw and the major transport routes/lines in the case study area (Fig. 3D). Purchase/sale transactions made during that period were particularly prevalent in the towns situated in the suburbs of Warsaw, where approx. $81 \%$ of all transactions were conducted. The urban communes of Marki and Ząbki saw the highest number of real estate transactions (over 1,500). Apart from the suburban area, considerable movement on the real estate market (over 50 transactions) was recorded in territorial units along the main transport routes and in the northern part of the case study area. The lowest number of real estate transactions (1-10 transactions) was visible in the eastern part of the case study area.

When it comes to real estate types: dwellings, developed real estate with residential buildings, and undeveloped real estate, the highest number of transactions (51\%) concerned dwellings (5,500). The vast majority of these transactions took place in the Ząbki and Marki communes (1,500 transactions each), while the lowest number of these transactions was

\footnotetext{
${ }^{4}$ Public services - administrative services, social services (which include, i.a., education, culture, health care, social assistance) and municipality services (including water supply, sewage treatment, thermal energy, electricity, waste management, communication services, road maintenance) have a major impact on the location of companies operating in the trade and services section, especially those operating in municipal services, business environment institutions and design and advertising companies.
} 


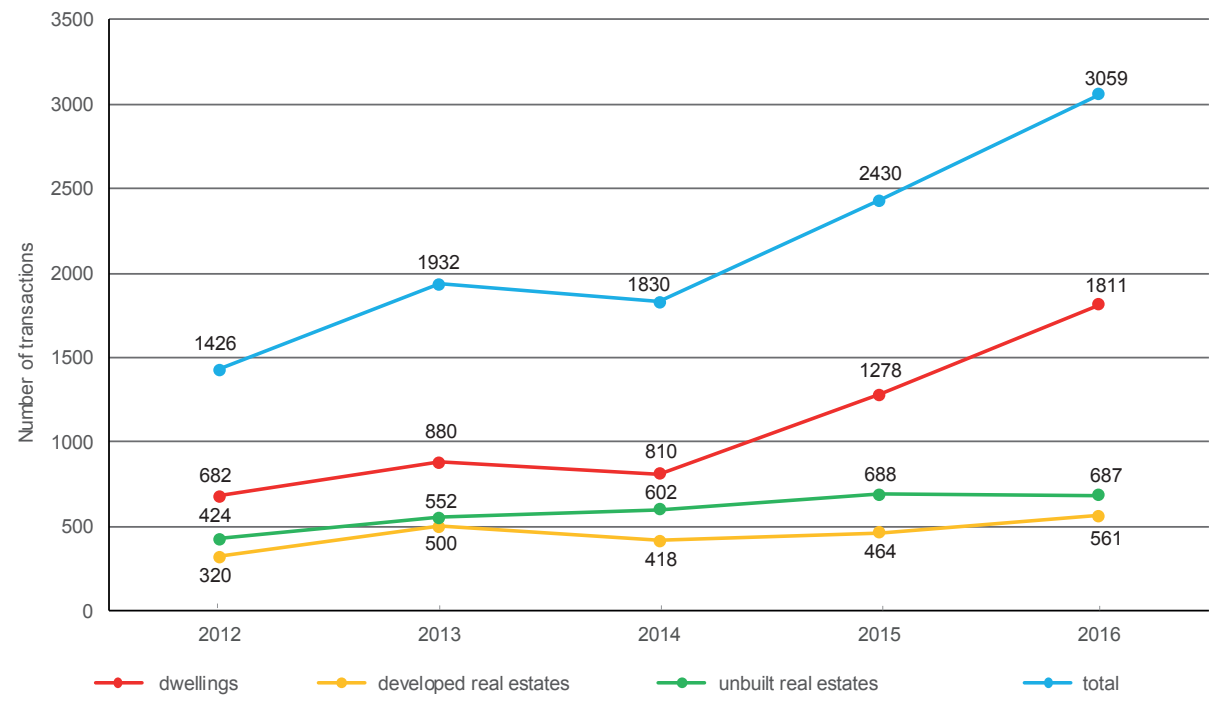

Fig. 4. Total number of conducted transactions and the number of conducted transactions by real estates types between 2012-2016

Source: study of the MBPR on the basis of data of county offices

conducted in rural communes. Transactions concerning unbuilt real estate made up $28 \%$ of all transactions carried out in the case study area $(2,900)$. The highest number of transactions of this type was completed in urban-rural communes $(1,200)$, while the urban communes of Zielonka and Ząbki saw the lowest number of such transactions. However, the highest share of undeveloped real estate in the total number of transactions $(70-85 \%)$ was recorded in rural communes. The remaining 2,300 transactions involved developed real estate with residential buildings. The highest number of such transactions took place in the Rembertów district of the capital city of Warsaw and in Marki. There, the number of real estate transactions grew, but this increase was not steady in character, which may have been caused by, for example, changes in the government housing policy and credit terms of financial institutions (Fig. 4).

The investments in the field of transport in 2012-2016 (E75 railway line modernization, construction of the Marki ring road - a section of national road no. 8 classified as an express road) had an impact on the real estate market in the case study area. This is visible in the relatively large number of transactions on the real estate market (over 50). The investments in transport infrastructure, which would eventually result in the reduction of time required to reach Warsaw, may have had an impact on the real estate transaction prices in the case study area. Future results, in particular those of the railway modernization, might have been an important factor that influenced the real estate prices in the analyzed period. It is impossible, however, to evaluate the impact of a single railway investment on the real estate market, the changes in which are dependent on a series of long-term actions and processes occurring in 
the area. Nevertheless, the growing interest in the purchase of dwellings and plots during the railway line modernization may reflect the railway project's impact on the real estate market which is affected by such investment processes in advance.

\section{Transport dimension}

Public transport offer

Apart from the above analysis of spatial and socio-economical processes in the analyzed area, changes in the dimension of transport were also examined, in accordance with the requirements of the NSB CoRe project. Inter alia, the public transport offer at railway stations and stops in the analyzed area was examined. ${ }^{5}$

The analysis focused on the offer of Koleje Mazowieckie (KM), which operates on regional and agglomeration railway lines at the request of the Regional Council of Mazovia - the organizer of public transport on a regional scale in Mazovia. The analysis took into account data from each year between 2011and 2018.

Due to the course of railway line no. 6 (E75), the majority of KM trains in the case study area end their courses at the Warszawa Wileńska terminus. Access from this terminus to the Warsaw city center is provided by a rapid transit line since 2015 (earlier by trams and buses). Changes are not required in the case of a direct railway connection to reach the cross-city railway line; however, the number of trains that go this way is much lower.

It should also be noted that in 2011-2015 there were approx. 10 extra connections starting from the Wołomin Słoneczna railway stop. This stop may be treated as the dividing line between regional and agglomeration railway operation. Due to modernization works on railway line no. 6, the lowest service level was recorded in 2016: only approx. 25 trains from Tłuszcz and approx. 20 extra trains from Wołomin. On the other hand, the number of trains from Mokra Wieś did not change considerably; it still oscillated around 20. The higher number of agglomeration trains than regional ones, which would continue in the subsequent periods, should be noticed. In particular, the number of connections from Tłuszcz has remained at just under 50 since 2017, so it is slightly lower than prior to 2014. On the other hand, the number of connections from Wołomin went up substantially - to almost 80, which is just under 20 more than during the previous period. The number of connections that arrive from beyond Tłuszcz did not change significantly and amounted to 23 in 2018 (Fig. 5).

The number of connections between railway line no. 6 and the cross-city railway line was considerably lower, regardless of the period (Fig. 6). Up to 2013, only trains from Wołomin reached the Warszawa Śródmieście railway stop. The number of connections from Wołomin to Warszawa Śródmieście and vice versa was 9-10 per day. In 2014-2015, such trains ceased

\footnotetext{
${ }^{5}$ In the analyzed area there are 12 passenger stations and stops. These are: between the Zielonka and Wołomin stations: the Kobyłka Ossów and Kobyłka stops; between the Wołomin and Tłuszcz stations: the Zagościniec, Dobczyn, Klembów, Jasienica Mazowiecka stops; after Tłuszcz station: the Chrzęsne and Mokra Wieś stops.
} 


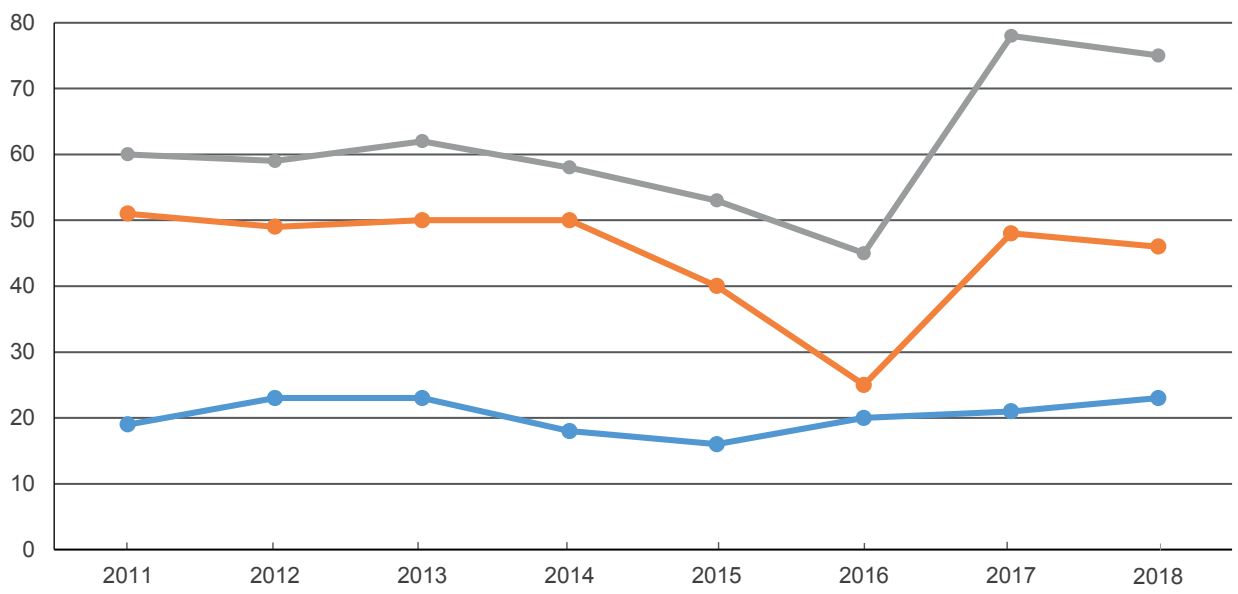

$\longrightarrow$ Warszawa Wileńska - Mokra Wieś —Warszawa Wileńska - Tłuszcz — $\multimap$ Warszawa Wileńska - Wołomin Słoneczna

Fig. 5. Number of Mokra Wieś-Tłuszcz-Wołomin-Warszawa Wileńska connections per day Source: study of the MBPR on the basis of Koleje Mazowieckie timetables

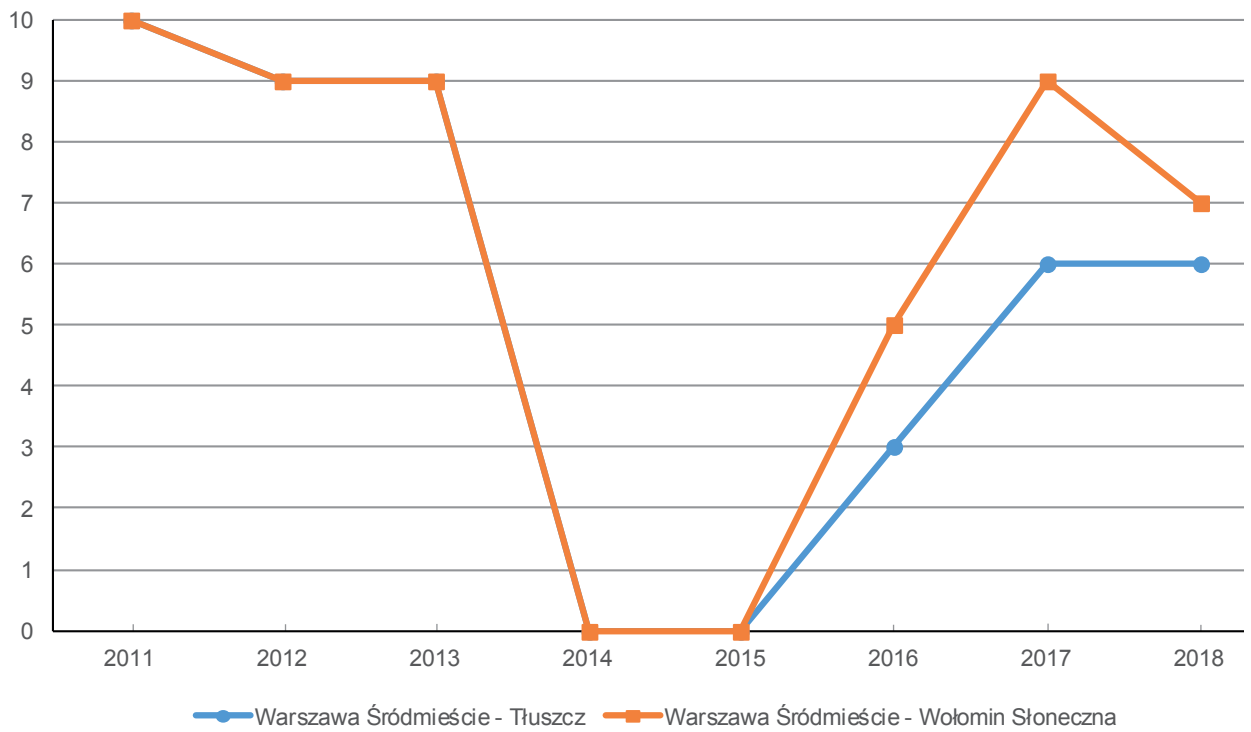

Fig. 6. Number of Warszawa Śródmieście - Tłuszcz/Wołomin connections per day Source: study of the MBPR on the basis of Koleje Mazowieckie timetables 
operating entirely. In the current timetable, the number of trips is between 5-6 from Tłuszcz and 1 extra from Wołomin. Therefore the frequency of services is lower than before the modernization of the railway line.

Currently, the journey time of a passenger train from Tłuszcz to Warszawa Wileńska is 39 minutes and 44 minutes from Mokra Wieś according to the timetable (Fig. 7). It takes 59 minutes for a passenger train to reach Warszawa Śródmieście from Tłuszcz. Generally, the journey time from Tłuszcz to Warsaw does not differ now from the journey time of 40 minutes in 2011. However, there were temporary increases in the journey time during the analyzed period. It was substantially longer in 2014-2015 and amounted to 53-54 minutes. A quicker way to reach Warsaw is a fast train operated by Koleje Mazowieckie but, unfortunately, it only reaches the Warszawa Wschodnia railway station. It takes 43 minutes for this train to reach Warsaw from Tłuszcz.

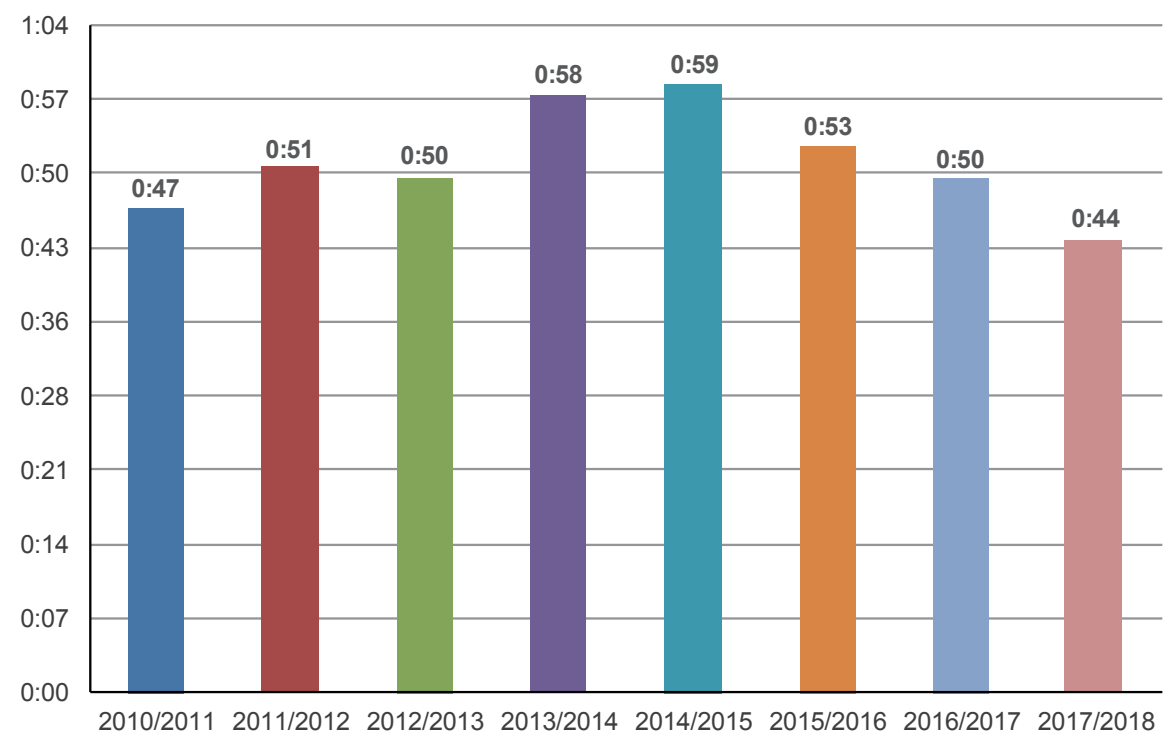

Fig. 7. Journey time of passenger trains on the Warszawa Wileńska - Mokra Wieś section by timetables valid in 2010-2017

Source: study of the MBPR on the basis of Koleje Mazowieckie timetables

\section{Quality of railway service - passengers' evaluation}

In order to evaluate the railway service quality and attractiveness, an indirect assessment was conducted through a survey among passengers on the E75 line's Warszawa Rembertów - Sadowne section. 344 persons were surveyed on workdays, during the morning and afternoon peak hours. Half of them used the railway to get to work, $21 \%$ - to school. 
The travelers' opinion on the connection offer around midday was the most favorable. They were also satisfied with the connection offer in the morning and in the afternoon. The respondents suggested that the number of connections at night is too small. They also had various opinions on the connection offer in the evening, depending on the respondents' age - those aged 25-34 and over 65 were dissatisfied, while the respondents aged 18-24 and below 18 were satisfied. The vast majority of the respondents were of the opinion that the train journey time along the analyzed section is short. They also think that it takes much less time to travel this distance by train than by car or bus. If trains are taken out of the equation, it seems that travelling by car is more convenient than by bus. The respondents were satisfied with train reliability. The vast majority of them believe that train delays, cancellations, or failures are very rare or rare

Two thirds of the travelers said that they use a monthly season ticket. Over one fifth of the respondents used one-way tickets to travel, while one tenth used other tickets, primarily Warsaw urban passes. One-way tickets were most frequently used by the oldest travelers, while the youngest ones generally used monthly season tickets. Passengers' educational background did not affect the type of purchased tickets because all the groups tended to choose the monthly season ticket most often. Only the travelers with primary education tended to choose one-way tickets as frequently as monthly season tickets. Nearly half of the respondents thought the ticket price too high, but nevertheless lower that costs associated with transport by bus or car.

The respondents were satisfied with travel comfort. They were satisfied with train comfort to the greatest extent. In addition, the majority of the travelers felt safe on trains and expressed a positive opinion as to train cleanliness. In the respondents' opinion, trains are too crowded.

The evaluation also included the distance and quality of the road between the railway stop/station and another means of transport as well as the time needed to reach it. The distance and quality of the road to reach a bicycle parking rack and the time needed to reach it turned out to be the most favorable; the bicycle parking rack was followed by a parking lot, and a bus stop, which was ranked the lowest. The shortest distance, the best quality of the road to reach a bicycle parking rack and the shortest time needed to reach it were recorded in Wołomin and Mokra Wieś, while the lowest values of these indicators were found in Jasienica. On the other hand, the shortest distance, the best quality of the road to reach a parking lot and the shortest time needed to reach it were recorded in Jasienica, while the lowest values of these indicators were found in Mokra Wieś. According to the respondents, the Wołomin and Tłuszcz railway stations and the Warszawa Mokry Ług railway stop feature the best access to a bus stop. This access was ranked the worst in Mokra Wieś and Dobczyn.

In general, only every twentieth traveller had a negative opinion concerning the quality of railway transport on the Warszawa Rembertów-Sadowne line. 


\section{Spatial availability of railway stations/stops using public transport}

The analysis took into account bus stops located in the closest vicinity of individual railway stations and stops, starting from the Zielonka railway station. Out of 11 railway stops and stations, local public transport stops were located near 6 of them. These were: Zielonka, Kobyłka Ossów, Kobyłka, Wołomin, Wołomin Słoneczna, Zagościniec, i.e. stations/stops situated near Warsaw as well as in the urban area of the north-eastern part of the Warsaw Metropolitan Area. Local public transport was not available near railway stops/stations located further from the capital.

In general, local routes operate through towns located next to the railway line. As a result, they make it possible to reach the railway station/stop from districts located far from it, and from which access on foot to such stations/stops is not convenient. Several lines travel to adjacent suburban towns located at a similar distance - up to a few kilometers - from the railway line. The route connecting Wołomin with Radzymin is an exception; Radzymin is the only larger center situated relatively far from railway line no. 6 . The number and frequency of runs for individual lines cannot be considered to meet the standards of local transport. The number of runs varies from approx. 10 to approx. 20 per day which results in a frequency of no more than twice an hour during peak hours. In effect, local bus routes are operated less frequently than the railway line in most cases, especially when sections of the railway line near Warsaw are considered.

No spatial integration of bus and railway stops on a small scale is another inconvenience. Walking distances, measured from the edge of the nearest railway platform to a bus stop, amount to 100-300 meters. Potential bus stops located at an even larger distance from the platform edge were not considered available.

\section{Spatial availability of railway stations/stops using private transport}

The case study area was analyzed in terms of access to the railway line by measuring the theoretical time needed to reach the nearest railway station or stop by car. The case study area was divided into three zones: with a travel time of up to 15 minutes, with a travel time of 15-20 minutes, and with a travel time of over 20 minutes. Towns and villages were included in individual zones in their entirety; if the town or village was situated on the border between zones, it was included in the zone in which most of its buildings were situated. The urban commune of Marki was not included in the analysis. Direct access from Marki to Warsaw is about as easy by car as to the analyzed railway stations/stops due to the fact that the town is located near Warsaw and next to express road S8 - while at the same time being located at a certain distance from railway line no. 6. A train station/stop is situated within a 15-minute distance by car in the towns of Ząbki, Zielonka, and Kobyłka, as they are located near the railway line. In the same zone is the urban-rural commune of Wołomin, followed by the rural commune of Klembów, and finally the urban-rural commune of Tłuszcz. Other communes are, at least partially, located in other zones. However, most of the population 
of these communes lives within the 15-minute radius. In three such communes, this is true for the vast majority of their population. In the case of the Radzymin urban-rural commune, the Radzymin town itself is in the 15-minute zone along with 19 out of 23 villages with an estimated population of 11,400. However, the remaining 4 villages with an estimated population of 2,400 are situated in the 15-20-minute zone. Similar proportions apply to the rural communes of Poświętne and Zabrodzie. 24 out of 27 Poświętne villages and 20 out of 22 Zabrodzie villages are in the 15-minute zone, which amounts to an estimated population of 5,500 and 5,300, respectively. In effect, 3 villages of Poświętne and 2 villages of Zabrodzie are situated in the 15-20-minute zone; their estimated populations are 700 and 500, respectively. The Dąbrówka commune is located at the furthest distance from railway line no. 6. The 15-minute zone encompasses 8 out of 27 Dąbrówka villages with an estimated population of 2,400 .

6 villages with an estimated population of 1,800 are situated in the 15-20-minute zone. The largest part of the commune, consisting of 13 villages with an estimated population of 3,900, is situated in the 20-minute zone. Apart from the Rembertów district and the urban commune of Marki, 193,000 inhabitants of the case study area live within a 15-minute distance from the railway stations and stops. 5,400 inhabit the 15-20-minute zone, while for 3,900 residents at the edges of the case study area it takes over 20 minutes to reach the railway station/stop by car.

The Wołomin Słoneczna railway stop is the only railway station/stop featuring designated parking spaces in the form of a "Park and Ride" parking lot. The parking lot has 140 car parking spaces and a roofed bicycle rack for 44 bicycles. $86 \%$ of the parking spaces were occupied on the day of the study. As for other railway stations and stops, travelers park their cars at free nearby parking lots (Zielonka, Tłuszcz, Wołomin, Kobyłka) or illegally next to the railway line, which is much more frequent. A lack of dedicated parking spaces also applies to travelers with bicycles. Bicycles may be parked at dedicated racks only at a few railway stations/stops (Wołomin, Zagościniec, Kobyłka, Chrzęsne, Klembów, Mokra Wieś).

To examine the private transport spatial availability of the railway stops and stations, the ArcGIS program and its Network Analyst tool were used. This analysis provided theoretical availability isochrones, i.e. the areas from which a given railway station/stop can be reached within a specified time frame -1-15 minutes by car. A travel time of up to 15 minutes was considered satisfactory. As for travelling on foot, the satisfactory time was 10 minutes. It was the most frequently indicated time by the survey respondents. Given the small scale of the study and the use of an isochrone map to cover a small area compared to the entire case study area, the study does not contain a graphical representation of pedestrian availability isochrones. The 15-minute by car isochrone was used to determine the estimated population andproportion of the inhabitants who live in the area with the easiest access to the railway line. 131 out of the 158 territorial units analyzed are within a 15-minute distance by car from railway stations and stops along the E75 railway line. The population of these territorial units is 235,241 , which accounts for $89.83 \%$ of all the inhabitants of the case study area (Fig. 8). 


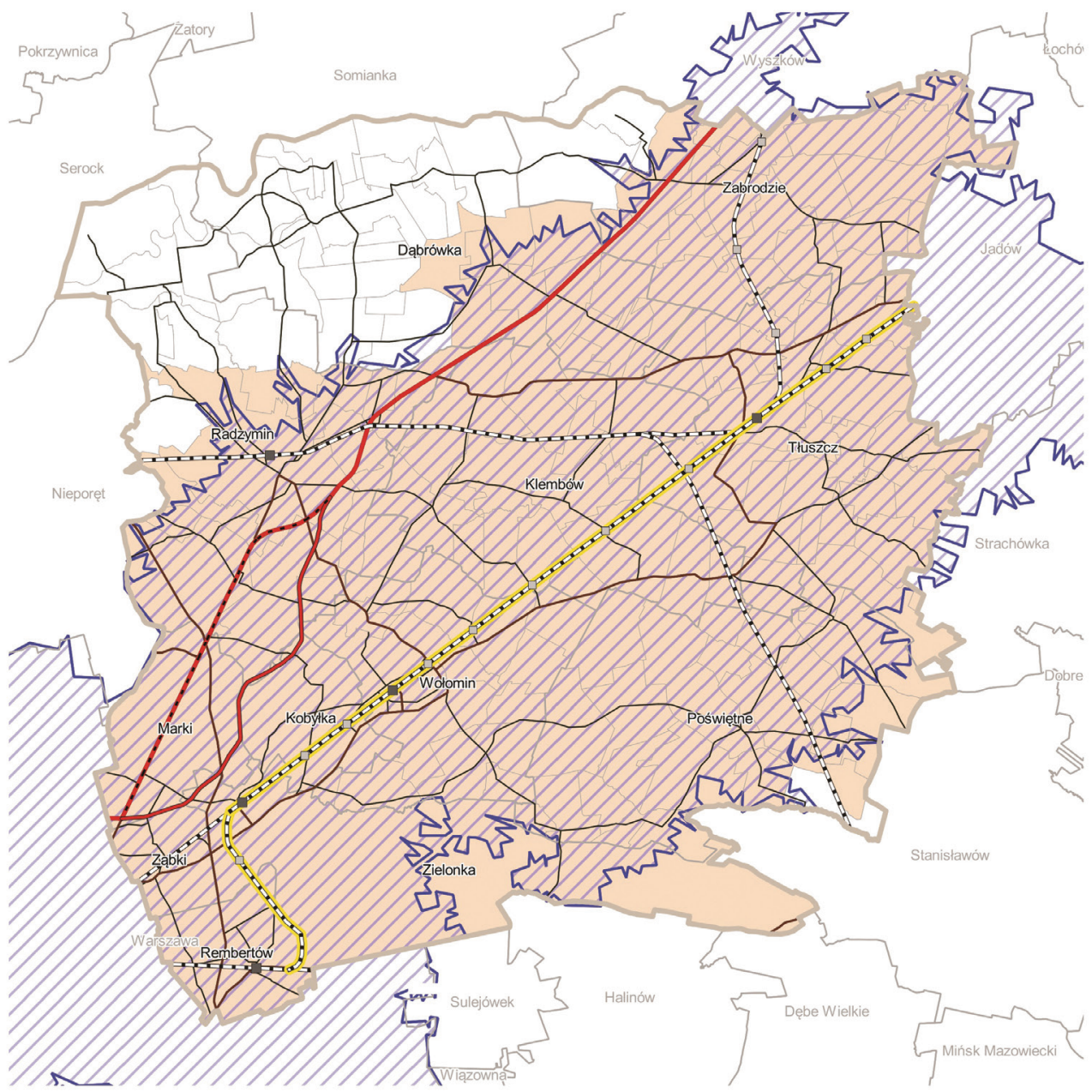

isochrone of $15 \mathrm{~min}$ access to railway stations and train stops

General markings

access area to railway stations and train stops within $15 \mathrm{~min}$

border of the case study

borders of communes borders of territorial units *

Transport systems

* borders of cities and district in rural communes

\footnotetext{
national roads

_ regional roads

- county roads

- . - rank reduction of the road

… the E75 railway line / other railway lines

ᄂ railway stations

$\square \quad$ train stops
}

Fig. 8. Area within a 15-minute car journey to railway stations/stops on the E75 railway line

Source: study of the MBPR on the basis of the TBD and transport network 


\section{Summary}

The spatial, socio-economic and transport processes discussed above are the outcome of conditions and various ongoing processes that often result from historical conditions, the distance from main urban centers and regional or national trends. It is extremely difficult to identify the impact of one factor on the above-mentioned processes. In addition, due to the infrastructural character of the investment in the E75 line's modernization, the trends in the area will be possible to identify at least several years after the modernization is finished. Nevertheless, taking the conditions into account, the case study attempted to analyze the intensity of spatial phenomena which may be indirectly influenced by the implementation of the railroad modernization project. The results of this study will be used to produce the joint transnational spatial vision of the North Sea-Baltic Sea corridor and to update the strategic and planning documents of the Mazovia Region.

\section{Legal acts and documents}

Plan zagospodarowania przestrzennego województwa mazowieckiego, uchwała nr 180/14 Sejmiku Województwa Mazowieckiego z dnia 7 lipca 2014 r. (Dz.Urz. Woj. Maz. z 2014 r., poz. 6868).

Rozporządzenie Rady Ministrów z dnia 24 grudnia 2007 r. w sprawie Polskiej Klasyfikacji

Działalności (Dz.U. z 2007 r., poz. 1885).

Ustawa z dnia 27 marca 2003 r. o planowaniu i zagospodarowaniu przestrzennym (Dz.U. z 2017 r., poz. 1073).

Ustawa z dnia 8 marca 1990 r. o samorzadzie gminnym (Dz.U. z 2016 r., poz. 446).

\section{References}

Atlas historyczny Polski, Mazowsze w drugiej połowie XVI wieku, 1973, Instytut Historii, PAN, Warszawa.

Dziemianowicz W., Mackiewicz M., Szmigiel-Rawska K., 2014, Diagnoza obszaru metropolitalnego Warszawy, Raport syntetyczny, Geoprofit, Ekorys, Warszawa.

Kazimierski J., 1998, Wołomin na tle innych nowych miast podstołecznych w latach 1896-1919, Rocznik Mazowiecki, 10, Mazowieckie Towarzystwo Naukowe, Warszawa.

Liszewski K., 2012, Geografia urbanistyczna, Wydawnictwo Naukowe PWN, Warszawa.

Trautmann C., 2016, Korytarz sieci bazowej Morze Pótnocne-Bałtyk, Drugi Plan Pracy Koordynatora Europejskiego, European Commission. 


\section{Other Sources}

Propozycje delimitacji Obszaru Metropolitalnego Warszawy. Raport z badania w ramach projektu Programowanie Rozwoju Obszaru Metropolitalnego Warszawy (PROM).

Transport pod lupa. Raport 2013, 2014, Europejski Fundusz Leasingowy, Warszawa.

\section{Wpływ modernizacji linii kolejowej E75 na rozwój Obszaru Metropolitalnego Warszawy}

\section{STRESZCZENIE}

Celem artykułu jest przedstawienie najważniejszych wyników badań przeprowadzonych na potrzeby Studium wpływu modernizacji linii kolejowej E75 na rozwój Obszaru Metropolitalnego Warszawy, Przedmiotowe opracowanie powstało w ramach projektu NSB CoRe (North Sea Baltic Connector of Regions). W artykule zaprezentowano najważniejsze wnioski z przedmiotowego Studium, opisujące zmiany, które zaszły na obszarze badań (zawartego w granicach OMW, obejmującego gminy położone w zasięgu $3 \mathrm{~km}$ od linii kolejowej E75 oraz gminy, przez które przebiega droga krajowa nr 8/S8), w okresie trwającej modernizacji linii E75. W tym celu skoncentrowano się na analizie zmian w przestrzeni osadniczej oraz w zakresie funkcjonowania transportu kolejowego i oceny przez podróżnych przyjętych usprawnień. Opisano wnioski z analizy zmian w wymiarze funkcjonalno-przestrzennym i społecznogospodarczym obszaru badań w zakresie: wydanych pozwoleń na budowę, zmiany liczby ludności, zarejestrowanych podmiotów gospodarczych osób fizycznych, transakcji zawartych na rynku nieruchomości. W artykule przedstawiono również zmiany, które zaszły $\mathrm{w}$ okresie modernizacji $\mathrm{w}$ zakresie transportu obejmujące ocenę jakości usług przewoźników kolejowych realizowanych na linii E75, opinie pasażerów na temat funkcjonowania transportu kolejowego oraz powiązania kolei bałtyckiej z alternatywnymi środkami transportu.

Słowa kluczowe: Obszar Metropolitalny Warszawy, linia kolejowa E75, korytarz transportowy Morze Bałtyckie-Morze Północne, Rail Baltica, projekt NSB CoRe

\footnotetext{
MSc Eng. Bartłomiej Drąg - graduate of economics, Technical University of Radom, civil servant, contact: Mazovian Office for Regional Planning in Warsaw, territorial office in Radom, ul. Mokra 2, 26-600 Radom, e-mail: bdrag@mbpr.pl

mgr Bartłomiej Drag - absolwent ekonomii w Politechnice Radomskiej, pracownik administracji publicznej, Mazowieckie Biuro Planowania Regionalnego w Warszawie, OT Radom, ul. Mokra 2, 26-600 Radom, e-mail:bdrag@mbpr.pl
}

mgr inż. Dariusz Piwowarczyk - graduate of spatial management at UWM, civil servant, contact: Mazovian Office for Regional Planning in Warsaw, territorial office in Siedlce, ul. Pułaskiego 19/21, 08-110 Siedlce, e-mail: dpiwowaczyk@mbpr.pl

mgrinż. Dariusz Piwowarczyk - absolwent gospodarki przestrzennej UWM, pracownik administracji publicznej, kontakt:Mazowieckie Biuro Planowania Regionalnego w Warszawie, OT Siedlce, ul. Pułaskiego 19/21, 08-110 Siedlce, e-mail:dpiwowaczyk@mbpr.pl 